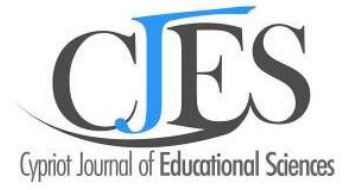

Volume 16, Issue 4, (2021) 1631-1642

\title{
Using self-assessment instruction to develop primary school students' self-esteem in inclusive practice in Kazakhstan
}

\author{
Almagul Kalykbayeva ${ }^{1}$, Abai Kazakh National Pedagogical University, Dostyk ave.13, 050010, Almaty, \\ Kazakhstan, almagulkalykbaeva@yandex.ru, https://orcid.org/0000-0001-5214-9526 \\ Akmaral Satova², Professor of Chair of Psychology, Abai Kazakh National Pedagogical University, Dostyk ave.13, \\ 050010, Almaty, Kazakhstan, https://orcid.org/0000-0002-2537-7184
}

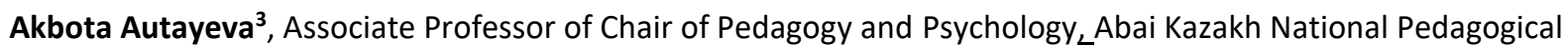
University, Dostyk ave.13, 050010, Almaty, Kazakhstan, https://orcid.org/0000-0003-4736-3004

Ainur Ospanova4, senior lecturer, Kazakh National Women's Pedagogical University Aitekebi st. 99, 050010, Almaty, Kazakhstan, https://orcid.org 0000-0002-4782-2568

Aigul Suranchina5, Doctoral student, Abai_Kazakh National Pedagogical University, Dostyk ave.13, 050010, Almaty, Kazakhstan, https://orcid.org 0000-0002-8006-8966,

Uaidullakyzy Elmira6* ${ }^{*}$ PhD doctor, senior lecturer, Abai Kazakh National Pedagogical University, Dostyk ave.13, 050010, Almaty, Kazakhstan, https://orcid.org/0000-0002-5613-4871

\section{Suggested Citation:}

Kalykbayeva, A., Satova, A., Autayeva, A., Ospanova, A., Suranchina A., \& Elmira, U., (2021). Using self-assessment instruction to develop primary school students' self-esteem in inclusive practice in Kazakhstan. Cypriot Journal of Educational Science. 16(4), 1631-1642. https://doi.org/10.18844/cjes.v16i4.6049

Received from April 10, 2021; revised from June 20, 2021; accepted from August 15, 2021.

C2021 Birlesik Dunya Yenilik Arastirma ve Yayincilik Merkezi. All rights reserved.

\begin{abstract}
The article presents an analysis of an experimental work. The purpose of the article is to analyze the effect of special selfassessment instruction on the self-esteem level of primary school students with and without special needs. The study's participants were the students of inclusive classes of two state schools in Almaty (Kazakhstan). A total of 283 students participated in the study, 17 of whom were students with special educational needs (SEN), and 266 - students without SEN. The study was conducted in the form of a quasi-experimental study. For the data analysis, the quantitative method of analysis was used. In analyzing the data, descriptive statistics (average value, standard deviation) as well as the non-parametric paired samples t-test and McNemar criterion tests were used. The study results showed a positive effect of self-assessment instruction on the students' level of self-esteem with and without SEN.
\end{abstract}

Keywords: self-assessment, students, primary school, special needs, inclusive education; 

primary school students' self-esteem in inclusive practice in Kazakhstan. Cypriot Journal of Educational Science. 16(4), 1631-1642. https://doi.org/10.18844/cjes.v16i4.6049

\section{Introduction}

Inclusive education has become part of the modern education system, which includes teaching children with special needs in general education schools, eliminating discrimination, and creating favorable educational environment for every child (UNESCO, 2003). The Kazakh educational system adheres to the global principles and trends of education and aims at developing the personality of students with special needs and normative students. Art. 16 of the Law Republic of Kazakhstan "On education" notes that: "General educational programs of primary education are aimed at forming the child's personality, developing his individual abilities, positive motivation and skills in educational activities..." (Harris \& Brown, 2018).

The psychological basis for the development of a person who can find his place in life is adequate self-esteem (Andrianova, Vasilchikova \& Pletnikova, 2016). It is well known that self-esteem is an important self-learning component, which is determined by the peculiarities of a person's life and begins to form at an early age. The period of a child's study in lower grades is of special significance for the selfesteem formation process (Tereshchenko, 2017). At this very age stage, the types of activities and social contacts expand that create conditions for the self-esteem to become more differentiated, adequate, generalized, and independent.

Our opinion coincides with the opinion of the authors such as Chalkia (2012) and Anastasiadou (2013). We believe that an important tool for forming the adequate self-esteem of each student is the conduction of special tasks for self-assessment of academic achievements in a class. In such a case, selfassessment is understood to be the process of comparing real results with the planned targets (Ababei, Ababei, Dobrescu \& Ababei, 2019). Therefore, it is necessary to develop the adequate self-esteem through the organization of self-assessment of academic achievements of a primary school student from the initial stage of training. An important principle of the organization of this process is the gradual expansion of the self-assessment range at different stages of a lesson.

The problem of self-esteem and self-assessment becomes particularly relevant when it comes to the children with peculiarities of psychophysical development since the self-esteem of such children determines the success of their social integration (Aarabi, Abdi \& Heydari, 2018). Therefore, the study of the features of its formation and correction is of particular importance. Therefore, the purpose of the article is to analyze the effect of special self-assessment task on the primary school students' level of self-esteem. According to this purpose the following tasks were set:

1) to identify the initial level of self-assessment skills (abilities)

2) to conduct consolidation lessons with the use of special self-assessment tasks

3) to compare the self-assessment dynamics of primary school both two groups of students with and without SEN.

\subsection{Literature review}

The problem of self-assessment of academic achievements of the students has been attracting the attention of scientists since the early 2000s. Most researchers studied the development of selfassessment ability in adolescence and college age. Thus, according to Topping (2003), the selfassessment ability and progress in class are determined not by the age of the subject, but by the selfassessment practice. The other factors influencing the self-assessment ability include the nature of the 
learning objectives, the nature of the assessed results and the clarity of the assessment criteria, as well as the assessment tools. Besides, Ross (2006) argues that special training (teacher's instruction) of the students develops the self-assessment ability.

Andrade and Valtcheva (2009) highlighted several factors important for the successful selfassessment of the students: explanation of the criteria to the students for the assessment of their work, assistance, and time sufficient to review their work after the self-assessment procedure. Selfassessment contributes to learning, including in-depth and continuous learning, makes the students feel that they control their assessment, develops autonomy and cognitive skills, contributes to a better understanding of the learning material, and improves the quality of work (Thi Le, Pham, Nguyen \& Tran, 2021). Besides, self-assessment reduces stress and increases personal and intellectual development and social skills. Harris (2014) argues that self-assessment increases performance and learning, while McMillan and Hearn (2008) believe that self-assessment increases motivation.

Alonso-Tapia and Panadero (2010) note that self-regulation is the result of a self-assessment procedure that has not been sufficiently investigated. However, we should note that self-assessment was mainly concentrated on the students of higher educational institutions (Panadero et al., 2012). Besides, Wong (2014) emphasizes that self-assessment ability has been studied more in higher education institutions than in the field of primary education.

The study of the self-assessment influence covers a wide range of applications, including written works in English (Montaner, 2020), sociological studies (Radid, Lotfi \& Akoul, 2020), mathematics (Stallings \& Tascione, 1996), natural sciences, and External evaluation of educational achievements (Akoul, Lotfi \& Radid, 2021). In each case, the students were engaged in written forms of self-assessment with the use of test papers and tests, as well as oral forms of self-assessment.

The study by Andrade et. all (2009) was aimed at establishing a relationship between self-assessment and writing essays and compositions by the students of the seventh and eighth grades. The group of researchers found a positive correlation between self-esteem and quality of writing, especially among girls. Ross (2006) argues about weak written works at the middle level (fourth, fifth, and sixth grades). The students with self-assessment skills outperformed their peers in terms of essays in the comparative study group. Such indicators as the sentence structure, grammar and spelling were in the first place.

Math teachers Stallings \& Tascione (1996) used self-assessment of students in secondary school and college in math classes. The teachers found that the self-assessment process may "improve their performance, help in the development of their communication skills and increase their math vocabulary." The self-assessment process is an important element of the evaluation process since the students receive appropriate feedback and continue to improve (Zapitis, 2011). However, if we dedicate some time to this process during a class, it will prove true, as it makes students more independent and responsible for their learning (Harris \& Brown, 2018). 
The purpose of self-assessment is to engage the students as active participants in their own learning and to reflect the results of their efforts. Since the main idea of self-assessment is to ensure that a child achieves a learning goal and realizes own achievements (Ratminingsih, Artini \& Padmadewi, 2017). Besides, Thi Le et al., (2021) argue that self-assessment reduces stress and improves personal and intellectual development and social skills, while McMillan and Hearn (2008) confirm that selfassessment increases motivation.

Self-assessment is a key component of the formative assessment, during which the students analyze the quality of their work and assess the extent, to which the formulated goals, principles and criteria are reflected, as it is an assessment procedure (Andreeva, 2005). So, according to some researchers, the basic meaning of self-assessment is self-control of a student, his self-regulation, and independent examination of own activities, and self-discipline (Matveeva, Pankova, Patrikeeva, 2013). Adequate selfassessment of own academic achievements confirms the adequacy of a person (Dzhioeva, 2018).

In inclusive classes, the priority is given to the development of strategies and the types of daily practices in class, which improves learning not only for children with SEN but for all children (Ainscow, 2007).

In our study, we consider self-assessment as a specially arranged process implemented in primary schools in the context of inclusive education. The system of special tasks for self-assessment of academic achievements is based on Bloom taxonomy (Bloom, 1988). The tasks are prepared in a level hierarchy for mastering the elementary basic knowledge of primary school in accordance with the SMART goals Kotova et all (2015), i.e., the goals of each task performed are based on an unambiguous assessment criterion. At the end of each task, the students are provided with independent activity on self-assessment of their tasks.

\section{Methods}

\subsection{Participants}

The study involved 283 primary school students, among them: 17 children with special needs (12 students with developmental delays, 1 autist, 2 children with $\mathrm{Cl}, 1$ mentally challenged $(\mathrm{m} / \mathrm{c})$ student, and 1 student with ADHD. Among them, there are 6 students with special needs from the 3rd grade, 7 students from the 2 nd grade, and 4 students from the 1st grade. The study also involved 266 students without SEN. 99 students from the 1st grade, 82 students from the 2 nd grade, and 85 students from the 3rd grade.

The experimental study consisted of three stages.

\subsection{Instrument}

The tool used to determine primary school students' levels of self-esteem was developed by the researcher in the form of self-assessment evaluation form. The evaluation form was consisted of special questions such as: Do you love yourself? Have you got many friends at school? Is it interesting for you to spend time at school? etc. The evaluation form was designed as a series of three-point Likert-type 
scale (3- sufficient; 2 -partially sufficient; and 1-insufficient). The participated were assessed during the short interview with the researcher.

\subsection{Experimental part}

At the first stage, students from grades 1 to 3 were tested with the use of the Ladder technique by V. G. Shur. The purpose of the technique is to study the self-esteem of children of primary school age.

At the second stage of the study, a system of special tasks for the formation of self-assessment skills of students at different stages of a class in primary school was implemented within four weeks.

At the third stage of the study, the influence of special tasks of the self-assessment levels of students based on the processing of the results obtained using the computer program SPSS 23.0. and the Mann-Whitney, Wilcoxon, and McNemar criteria was determined.

\subsection{Data analysis}

To identify the participants level of self-esteem descriptive statistics was conducted. During the analysis nonparametric tests were used such as Paired samples t-test, Wilcoxon test, and McNemar criteria test.

\section{Results}

The results of the Ladder technique by Shur (1981) showed that $22 \%$ of the students have inflated self-esteem, $57 \%$ of the students have an adequate level, and $21 \%$ have deflated self-esteem. We should note that deflated self-esteem of a primary school student is admissible, since at this age self-esteem is formed that is close to an adequately differentiated one. Such students are more self-confident; they often initiate games or activities and actively participate in class or school activities. Sometimes, they can break the rules, cry out during classes, and easily raise a hand from the place. Deflated self-esteem is manifested when a child cannot cope with a task or has difficulties.

After the control experiment, the self-esteem of the tested persons became more adequate. The children with SEN became inclined to analyze their behavior and assess themselves and their activities more adequately. They became more self-confident and well-balanced, easier contact with their peers and teachers. The predominance of adequate self-esteem of primary school students in an inclusive environment indicates psychological and emotional well-being in this environment.

In connection with the tasks of the experiment, the descriptive statistics was presented (Table 1).

Table 1. Comparative indicators of self-assessment of students at the confirming stage of the experiment.

\begin{tabular}{llll}
\hline & Number of students & Mean & Standard deviation \\
\hline Students without SEN & 266 & 2,50 &, 719 \\
Students with SEN & 17 & 2,11 &, 871 \\
\hline
\end{tabular}



primary school students' self-esteem in inclusive practice in Kazakhstan. Cypriot Journal of Educational Science. 16(4), 1631-1642. https://doi.org/10.18844/cjes.v16i4.6049

Students with special needs demonstrated an average score of 2,11, while the normative students demonstrated a higher average score of 2,50.

Data for comparing the results at the control stage of the experiment of testing the group of students without disabilites according to the paired samples t-test.

Table 2. Dynamics of self-assessment of students without disabilities according to the student's t-criterion.

\begin{tabular}{lllllll}
\hline & Number & $\begin{array}{l}\text { Average } \\
\text { value }\end{array}$ & $\begin{array}{l}\text { Standard } \\
\text { deviation }\end{array}$ & t & Df & P \\
\hline Students without disabilities & 266 &,- 42578 &, 93848 & $-7,259$ & 255 &, $000^{*}$ \\
\hline $\mathrm{p}<.05$. & & & & & &
\end{tabular}

Finally (see Table 2), a statistically significant difference was found because of preliminary and final testing of normative students $(t=-7,259 ; p=0,000)$ both at the confirming and control stage of the study.

At the control stage of the study, the students without disabilities were tested for adequate selfassessment with the use of the McNemar criterion test. (Table 3). So, 172 (64,7\%) primary school students assessed their academic achievements adequately, the dynamics because of the study can be traced, the changes were statistically significant, $p=0,01$.

Inadequacy of assessment has also decreased from 25,9\% (69 students) to $21,8 \%$ (58 students). At the control stage, 36 students $(13,5 \%)$ demonstrated non-assessment, while at the confirming stage, these indicators were significantly higher than $60(22,6 \%)$ students, although the changes were not statistically significant, $p=0,818$ (the McNemar criterion testwas used).

Table 3. Comparative indicators of self-assessment of the students at the control stage of the experiment (the McNemar criterion was used).

\begin{tabular}{llll}
\hline Self-assessment & Confirming state & Control stage & $\mathrm{P}$ \\
\hline Adequate self-assessment & $137(51,5 \%)$ & $172(64,7 \%)$ & 0,010 \\
Inadequate self-assessment & $69(25,9 \%)$ & $58(21,8 \%)$ & 0,818 \\
Non-assessment & $60(22,6 \%)$ & $36(13,5 \%)$ & \\
Total & $266(100 \%)$ & $266(100 \%)$ & \\
\hline
\end{tabular}

The results of the analysis obtained from children with special needs.

At the formative stage of the experiment, we considered the students with special needs in a rank correlation: high, medium, low, zero. The results are given in table 4, (Figure 1).

Table 4. Dynamics of self-assessment of academic achievements of students with special needs (in absolute terms).

\begin{tabular}{llllll}
\hline Period/levels & High & Medium & Low & 0 & Total \\
\hline Before the experiment & 2 & 2 & 10 & 3 & 17 \\
After the experiment & 3 & 3 & 9 & 2 & 17 \\
\hline
\end{tabular}


As we see, after using a system of special training, a positive trend is observed.

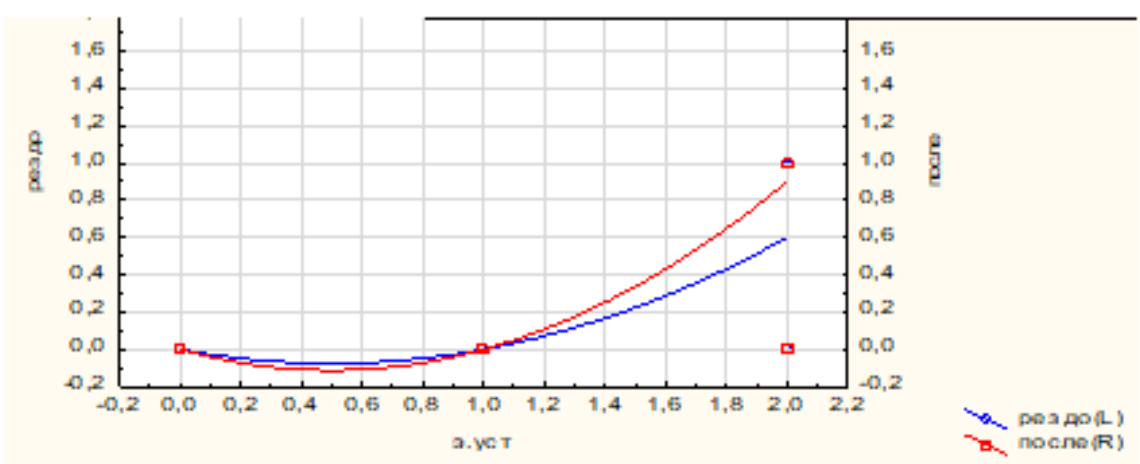

Self-assessment skills of students with SEN

Figure 1. Comparative indicators of self-assessment of students with special needs (control experiment)

The data analysis with the use of non-parametric statistics allowed to establish that there is a clearly expressed negative relationship between the age of the children tested and the number of cases with a lack of responses to the task: $R=-1.0, p<0,05$. That is, the older the child became, the more reliably the total number of cases with a lack of response to the task decreased. We should note that if the changes in a lack of response to the task reliably decreased with the age of students, as we can see from figure 1 (blue curve), the changes in self-esteem were more complex: it decreased by the 2 nd grade -8 years, then sharply rose in the 3 rd grade (red curve). Apparently, up to the age of 8 years, the children are not completely self-confident, but with age, they get an adequate self-assessment and independent selfcomprehension (Vitalevna \& Vladimirovna, 2016).

At the third stage of the study, the results of the students with special needs before and after the experiment were compared. In this case, 6 students with special needs were from the third grade, 7 students - from the second grade, and 4 students - from the first grade. For this purpose, paired samples t-test was conducted, the results of which are given in Table 5.

Table 5. Dynamics of self-assessment of students with special needs before and after a formative experiment (according to the Wilcoxon test).

\begin{tabular}{|c|c|c|c|c|c|}
\hline & & Number & $\begin{array}{l}\text { Average } \\
\text { value }\end{array}$ & $\begin{array}{l}\text { Sum } \\
\text { indicators }\end{array}$ & of $z$ \\
\hline \multirow{2}{*}{$\begin{array}{l}\text { Students with } \\
\text { special needs }\end{array}$} & $\begin{array}{l}\text { Negative } \\
\text { indicators }\end{array}$ & $0^{\mathrm{a}}$ & ,00 & .00 & \multirow[b]{2}{*}{$2,121^{b}, 034^{*}$} \\
\hline & $\begin{array}{l}\text { Positive } \\
\text { indicators } \\
\text { Neutral } \\
\text { indicators } \\
\text { Total }\end{array}$ & $\begin{array}{l}5^{b} \\
12^{c} \\
17\end{array}$ & 3,00 & 15,00 & \\
\hline
\end{tabular}

$* p<.05$. 
Kalykbayeva, A., Satova, A., Autayeva, A., Ospanova, A., Suranchina A., \& Elmira, U., (2021). Using self-assessment instruction to develop primary school students' self-esteem in inclusive practice in Kazakhstan. Cypriot Journal of Educational Science. 16(4), 1631-1642. https://doi.org/10.18844/cjes.v16i4.6049

As we see, the results of the paired samples t-test showed that there is a statistically significant difference between the scores of the group of students with special needs after the experiment $(p<$ $.05)$.

Self-assessment of students with special needs at the control stage of the experiment showed insignificant changes (Table 6).

Table 6. Comparative indicators of self-assessment of students with special needs according to the McNemar criterion

\begin{tabular}{llll}
\hline Self-assessment & Confirming & control & $P$ \\
\hline Adequate self-assessment & $4(23,5 \%)$ & $6(35,3 \%)$ & \\
No result & $13(76,5 \%)$ & $11(64,7 \%)$ & 0,500 \\
Total & 17() $100 \%)$ & $17(100 \%)$ & \\
\hline
\end{tabular}

13 students (76,5\%) out of 17 students with special educational needs, showed no results at the confirming stage of the experiment, but $4(23,5 \%)$ students with SEN showed insignificant changes. At the control stage of the experiment, $6(35,3 \%)$ out of 17 students with special needs demonstrated insignificant changes; $p=0,500$ (the McNemar criterion test was applied).

\section{Discussion}

According to the results of the study, we can note that both children with and without special educational needs do not know the techniques of self-assessment of academic achievements, and their self-assessment is mainly inadequate (by children with SEN - mainly deflated, by children without SEN mainly inflated). However, the systematic provision of special training tasks based on the SMART technology allows to form their skills of self-assessment of academic achievements and correct selfesteem to some extent. At the same time, children without SEN have more pronounced dynamics, a higher degree of motivation, and the ability to assess their achievements more consciously compared to children with SEN (Tashkenbayevna et al., 2018; Zhumabayeva et al., 2019).

It is also established that to increase the objectivity of self-assessment of academic achievements of the students and identification of the causes of arising difficulties, it is necessary to consider the ratio between the actual (ALD) and potential level of development of the students (zone of proximal development) for each level of mastering the training material. In self-assessment, the activity of the student is welcomed, but the student himself cannot show it; in this educational process, the teacher plays the role of an initiator as the organizer of this process. One of the key elements of this process relates to the teacher's role in deploying available tools and resources to support learning, with an appropriate combination of learning strategies (Uhlirova, 2018; Tukaiev et al., 2018).

Summing up the results of the experiment, we can say that in inclusive education under identical experimental conditions, primary school students demonstrated different levels of acquiring selfassessment skills and mastering elementary basic knowledge. Most normative students, 64,7\%, acquired self-assessment skills and elementary basic knowledge. Now of instruction, they demonstrated the ability to program their activities and bring their actions into line with this algorithm for the entire allocated period, as well as the adequacy of assessment to the task (Riga, loannidi \& Papayiannis, 2020). 
According to the results of statistical analysis, it was established that the system of special tasks influenced the level of children with special educational needs, but this influence was insignificant. Programming of actions under this algorithm (instruction) caused difficulties for 3,9\% of students with special needs, as the specific features and the personality of the students manifested. However, we found the dynamics of the primary school students over a short period and small progress in acquiring skills among the children with special educational needs. It proves the effectiveness of the developed system of special tasks both for the children with normative development and special needs (Bagila et al., 2019; Hamdan, Isik \& Jallad, 2019).

\section{Conclusions}

The main peculiarity of the self-assessment process is the system of tasks used by the primary school teachers in the formation of self-assessment skills in educational activities, which constitutes a level-bylevel performance of actions and a natural integration (embeddedness) into the educational process.

The organization of self-assessment of academic achievements of the students based on the principles of humanism, considering specific and individual psychological characteristics of each child with special needs, will contribute to the personal development of the students, as the adequate and differentiated self-esteem is formed, which contributes to the development of self-regulation and selfcontrol of the students.

In inclusive classes, priority is given to the development of strategies and types of daily practice in class that improves learning not only for children with SEN but for all children. Therefore, selfassessment entails a whole sequence of actions: assessment of the results of own activities, realizing the correctness and accuracy of the task performed, rational use of class time, achievement of learning goals, mastering elementary basic knowledge. Thus, the study in class would be incomplete without the daily training provided by school practice. The formation of the self-assessment skill is a personal quality that represents the unity of cognitive, active, motivational, and emotional components.

\section{Acknowledgement}

We express our deep gratitude for the organization and conduction of the study to the administration, teachers, and students at the primary school of the secondary schools of Almaty.

\section{Conflict of Interests}

The authors declare no conflict of interest.

\section{References}

Aarabi, H., Abdi, M., \& Heydari, H. (2018). Effects of relaxation training to increase self-esteem in the University's graduate students. International Journal of New Trends in Social Sciences, 2(2), 32-38. https://doi.org/10.18844/ijntss.v2i2.3954

Ababei, C., Ababei, R., Dobrescu, T., \& Ababei, A. (2019). Study regarding the possibilities of increasing the selfesteem in 15-year-old pupils. New Trends and Issues Proceedings on Humanities and Social Sciences, 6(1), 65-71. https://doi.org/10.18844/prosoc.v6i1.4155 
Kalykbayeva, A., Satova, A., Autayeva, A., Ospanova, A., Suranchina A., \& Elmira, U., (2021). Using self-assessment instruction to develop primary school students' self-esteem in inclusive practice in Kazakhstan. Cypriot Journal of Educational Science. 16(4), 1631-1642. https://doi.org/10.18844/cjes.v16i4.6049

Ainscow M. (2007). Education for all: Making it happen. Support for Learning 10(4), 147 - 155. DOI: 10.1111/j.1467-9604. 1995.tb00031.x

Akoul, M., Lotfi, S.., \& Radid, M. (2021). Correlations of self-esteem with academic competencies and gender variations. International Journal of Learning and Teaching, 13(1), 01-12. https://doi.org/10.18844/ijlt.v13i1.5204

Alonso-Tapia, J., \& Panadero, E. (2010). Effects of self-assessment scripts on self-regulation and learning. Infancia y Aprendizaje, 33(3), 385-397. https://doi.org/10.1174/021037010792215145

Anastasiadou, A. (2013). Self-assessment: Its impact on students' ability to monitor their learning process in the English classroom and develop compensatory strategies. Research Papers in Language Teaching and

Learning, 4(1). Retrieved from http://rpltl.eap.gr/current-issue/table-ofcontents/18-alexandra-anastasiadou

Andrade, H. L., Wang, X., Du, Y., \& Akawi, R. L. (2009). Rubric-referenced self-assessment and self-efficacy for writing. The Journal of Educational Research, 102(4), 287-302.

https://doi.org/10.3200/JOER.102.4.287-302

Andrade, H., \& Valtcheva, A. (2009). Promoting learning and achievement through self-assessment. Theory into practice, 48(1), 12-19. https://doi.org/10.1080/00405840802577544

Andreeva, M. N. (2005). Self-assessment of a younger student in the educational process. Social research technologies. (3), 66-68.

Bagila, S., Kok, A., Zhumabaeva, A., Suleimenova, Z., Riskulbekova, A., \& Uaidullakyzy, E. (2019). Teaching Primary School Pupils Through Audio-Visual Means. International Journal of Emerging Technologies in Learning (iJET), 14(22), 122-140. https://online-journals.org/index.php/i-jet/article/view/11760

Bloom, B. S. (1988). Helping all children learn in elementary school and beyond. Principal, 67(4), 12-17.

Brown, G. T., \& Strijbos, J. W. (2016). The future of student self-assessment: A review of known unknowns and potential directions. Educational Psychology Review, 28(4), 803-830. https://doi.org/10.1007/s10648015-9350-2.

Chalkia, E. (2012). Self-assessment as an alternative method of assessing speaking skills in the sixth grade of a Greek state primary school classroom. Research Papers in Language Teaching and Learning, $3(1)$.

Retrieved from http://rpltl.eap.gr/previous-issues/volume-3-issue-1-february2012/table-of-contents/37-ekaterini-chalkia

Dzhioeva G.H. (2018). On the problem of forming the self-esteem of a primary school student. Azimuth of research: pedagogy and psychology, 7, 2(23-30)

Hamdan, S., Isik, B., \& Jallad, S. T. (2019). Impact of creativity in nursing education. New Trends and Issues Proceedings on Advances in Pure and Applied Sciences, (11), 39-45. https://doi.org/10.18844/gjpaas.v0i11.4312

Harris, L. R., \& Brown, G. T. (2018). Using Self-Assessment to Improve Student Learning. New York: Routledge.http://online.zakon.kz/Document

Kotova N.V., Ilyasova D.S., Zhurba L.V., Pazylova G.Sh., Rahymzhanova B.K. (2015). Formative assessment in education: SMART- goals and criteria of success. Autonomous Educational Organization "Nazarbayev Intellectual school", center of excellence, p. 42.

Matveeva E.I., Pankova O.B., Patrikeeva I.E. (2013). Criteria-based assessment in primary school (based on work experience). Publisher: “Vita-Press", $192 \mathrm{p}$. 
Kalykbayeva, A., Satova, A., Autayeva, A., Ospanova, A., Suranchina A., \& Elmira, U., (2021). Using self-assessment instruction to develop primary school students' self-esteem in inclusive practice in Kazakhstan. Cypriot Journal of Educational Science. 16(4), $1631-1642$. https://doi.org/10.18844/cjes.v16i4.6049

McMillan, J. H., \& Hearn, J. (2008). Student self-assessment: The key to stronger student motivation and higher achievement. Educational Horizons, 87(1). Retrieved from https://eric.ed.gov/?id=EJ815370

Montaner, S. (2020). EFL written competence through twitter in mobile version in compulsory secondary education. Global Journal of Foreign Language Teaching, 10(2), 101-110. https://doi.org/10.18844/giflt.v10i2.4665

Panadero, E., Tapia, J. A., \& Huertas, J. A. (2012). Rubrics and self- assessment scripts effects on self-regulation, learning and self-efficacy in secondary education. Learning and Individual Differences, 22(1), 806-813. https://doi.org/10.1016/j.lindif.2012.04.007

Radid, M., Lotfi, S., \& Akoul, M. (2020). Effects of academic results on the perception of competence and selfesteem in students' training. Global Journal of Guidance and Counseling in Schools: Current Perspectives, 10(1), 12-22. https://doi.org/10.18844/gigc.v10i1.4874

Ratminingsih, N. M., Artini, L. P., \& Padmadewi, N. N. (2017). Incorporating Self and Peer Assessment in Reflective Teaching Practices. International Journal of Instruction, 10(4), 165-184. https://doi.org/10.12973/iji.2017.10410a

Riga, A., loannidi, V., \& Papayiannis, N. (2020). Computer supported collaborative learning in Greek inclusive secondary education. International Journal of Special Education and Information Technologies, 6(1), 1828. https://doi.org/10.18844/ieset.v6i1.5365

Ross, J. A. (2006). The reliability, validity, and utility of self-assessment. Practical Assessment, Research \& Evaluation, 11(10), 1-13

Stallings, V., \& Tascione, C. (1996). Student self-assessment and self-evaluation. The Mathematics Teacher, 89(7), 548-554. https://doi.org/10.5951/MT.89.7.0548

Tashkenbayevna, N., Kenesbaev, S. M., Zhailauova, M. K., Elmira, U., Nurzhanova, S. A., \& Stambekova, A. S. (2018). Possibilities of the Subject 'Information and Communication Technologies' in Accustoming Primary School Students to Research Activities. International Journal of Interactive Mobile Technologies (iJIM), 12(6), 3546. https://doi.org/10.3991/ijim.v12i6.9622

Tehdit, H. (2020). Investigation of cognitive, psychomotor, and social emotional progress in primary schools by directors' ideas. International Journal of Innovative Research in Education, 7(1), 32-46. https://doi.org/10.18844/ijire.v7i1.5548

Tereshchenko E.S. (2017). Self-assessment in the structure of the personality of a primary school student. Bachelor, 34(31-34)

Thi Le, T. T., Pham, C. X., Nguyen, S. T., \& Tran, T. (2021). The capacity of formative assessment in teaching mathematics in primary schools by students: Analytical results from 11 universities in Vietnam. Ilkogretim Online, 20(1), https://www.ejmanager.com/mnstemps/218/218-1606797332.pdf?t=1606889255

Topping, K. (2003). Self and peer assessment in school and university: Reliability, validity, and utility. Retrieved from https://link.springer.com/chapter/10.1007/0-306-48125-1 4

Tukaiev, S., Dolgova, O., Lysenko, O., Fedorchuk, S., Havrylets, Y., Rizun, V., Vasheka, T., \& J. M. van den Tol, A. (2019). Amateur sport and emotional burnout formation in high school students. Contemporary Educational Research Journal, 9(4), 103-109. https://doi.org/10.18844/cerj.v9i4.4328

Uhlirova, M. (2018). Semantic space of elementary teacher attitudes towards computer teaching assistant. Global Journal of Information Technology: Emerging Technologies, 8(1), 01-09. https://doi.org/10.18844/gjit.v8i1.3334 
Vitalevna, P. T., \& Vladimirovna, R. T. (2016). Assessment Of Achievements of Students with Disabilities as A Problem of Effectiveness of Inclusive Educational Process1. Pedagogical Journal, 97. https://core.ac.uk/download/pdf/288343047.pdf\#page=97

Wong, H. M. (2014). I can assess myself: Singaporean primary students' and teachers' perceptions of students' self-assessment ability. Education, 44(4), 442-457. https://doi.org/10.1080/03004279.2014.982672

Zapitis, M. (2011). The effects of self-evaluation training on writing of students in grades 5 \& 6 (Master's thesis, University of Toronto, Toronto, Canada). Retrieved from https://tspace.library.utoronto.ca/bitstream/1807/29492/1/Zapitis Marina 201106 MA thesis.pdf

Zhumabayeva, Z., Uaisova, G., Zhumabayeva, A., Uaidullakyzy, E., Karimova, R., \& Hamza, G. (2019). Issues of Kazakh language teaching in elementary classes in terms of the meta-subject approach. Cypriot Journal of Educational Sciences, 14(1), 158-170. https://doi.org/10.18844/cjes.v14i1.4123 